\title{
Assessment of Moisture Response and Expected Durability of a Heritage Masonry Building Subjected to Projected Future Climate Loads of Ottawa, Canada
}

\author{
John A. Wells ${ }^{1}$, Michael A. Lacasse ${ }^{2}$ and Gary Sturgeon ${ }^{3}$ \\ ${ }^{1}$ Crosier Kilgour \& Partners Ltd., Consulting Structural Engineers, Winnipeg, Manitoba, Canada \\ ${ }^{2}$ Facade Systems and Products Group, Construction Research Centre, National Research Council of \\ Canada, Ottawa, Ontario, Canada \\ ${ }^{3}$ BBSTEK Ltd., Consultant \& Structural Engineer, Millarville, Alberta, Canada
}

\begin{abstract}
As part of the Canadian government's recent drive to the "on Greening Government initiative, heritage buildings forming part of the parliamentary precinct in Ottawa, Canada are to be retrofitted in the coming years to help reduce energy usage and decrease greenhouse gas emissions associated with heating and cooling. Increasing levels of GHG concentrations over time has the potential to raise the mean global temperature by +3.5 degrees. The predicted impact on Ottawa's climate will be significant, increasing precipitation annually by $14.4 \%$ and decreasing the January winter design temperature from $25^{\circ} \mathrm{C}$ to $-11.7^{\circ} \mathrm{C}$ or $53 \%$. In this paper, the moisture response of a heritage building located in Ottawa, Canada is determined from results of numerical simulations when subjected to both historical and projected future climate loads. Various insulation strategies for masonry wall systems were assessed. The objective was to decrease the energy demand associated with heating and cooling by applying insulation on the interior face of the masonry. Using future climate loads, results from hygrothermal modeling showed that although the climate change model produces higher volumes of annual precipitation, no deleterious levels of moisture build-up were observed in the wall system. In fact, moisture levels remained relatively consistent, irrespective of the insulation type applied to the interior face of the walls. Moisture content for all scenarios was well below critical saturation of the masonry materials. The warming climate has a dramatic effect by reducing the number of hours below freezing experienced by the interior brick wythe when interior insulation is applied. From the hygrothermal analysis, it was concluded that the warming temperatures will substantially reduce the number of hours the interior wythe of masonry experiences freezing temperatures which in turn, reduces the potential for freeze-thaw damage to the masonry. The interior application of moderate levels of insulation should therefore be considered for retrofit measures for this heritage building, located in Ottawa, Canada, without increasing the risk of damage to the wall.
\end{abstract}

Keywords: Climate Change, Durability, Historic Building, Hygrothermal Simulation, Masonry Walls, Moisture Response.

\section{Introduction}

There is overwhelming evidence that continued increases in world greenhouse gas (GHG) generation is impacting climate change on a global scale. Although Canada's contribution to world GHG's has been trending downward from $1.8 \%$ to $1.6 \%$ over the last 10 years, it remains $9^{\text {th }}$ overall in contribution to world GHG generation. Buildings in Canada contribute $12 \%$ of its overall GHG annual total and this number has remained relatively unchanged between 1990 and $2017^{2}$. Thus, significant room for improvement exists in Canada to decrease GHG's for both new and existing building stock.

The introduction of the National Energy Code of Canada for Buildings has initiated significant enhancements to reducing the GHG's of new buildings and additions to existing buildings; however, many existing buildings, and particularly heritage buildings are presently exempt from implementing the Code required changes to the building envelope to reduce the contribution of greenhouse gas generation associated with heating and cooling loads. 
As part of the Canadian government's recent drive to the "Greening Government" initiative, heritage buildings forming part of the parliamentary precinct district in Ottawa are to be retrofitted in the coming years to help reduce energy use for heating and cooling loads and ultimately decrease greenhouse gas emissions. Such measures may require intensive remediation and for heritage restoration projects may also involve changes to the building envelope, including but not limited to, increased thermal resistance of the wall system, enhanced precipitation managements strategies, and introduction of an air barrier. However, sufficient number of case studies exist to conclude that caution is required when introducing insulation to masonry wall systems on heritage buildings because of the changes in thermal and moisture loads can induce damage, (Wilkenson, De Rose; Wojcik, Bomberg) principally by freeze-thaw degradation.

Hygrothermal modeling is often used to assess the impact changes to materials and assemblies in the building envelope may have on the durability of the exterior walls, primarily due to cumulative moisture effects and the associated degradation actions. Hygrothermal modeling for heritage buildings present a unique challenge for analysis, primarily because owners of these buildings understandably have an entrenched expectation of a long Design Service Life for mass masonry wall systems. The impact of climate change creates a potential confounding error in the analysis if historical weather databases are used in the hygrothermal model rather than databases for the predicted future climate.

The purpose of this paper is to present the results of the predicted durability analysis of one of the several Parliamentary precinct buildings, specifically, the Wellington Building located at 180 Wellington Street in downtown Ottawa, Canada. A comparative study is completed on the hygrothermal analysis climatic data and a re with increasing levels moisture within wall existing and predicted
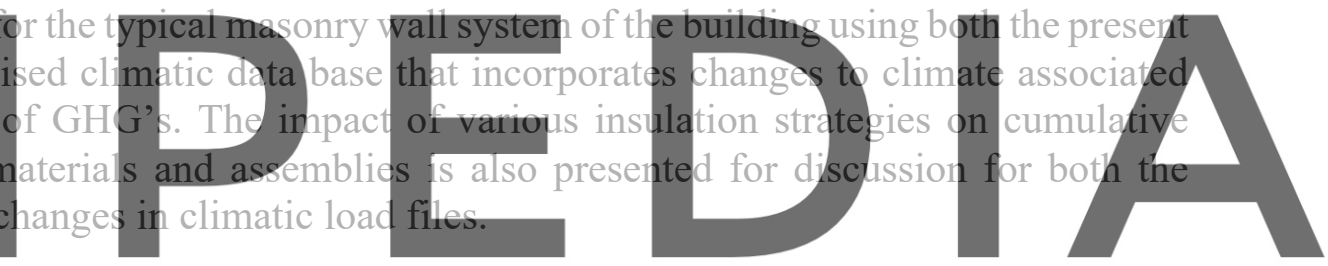

Register for free at https $/$ /wwww.scipedia.com to download the version without the watermark Many historical buildings have performed well for decades (Mario D. Gonçalves 2007) when perimeter steam was used to heat the building and no forced air ventilation systems, or humidification were implemented. The warmer masonry increased the moisture storage capacity of the masonry, reducing condensation potential. Unfortunately, many multi-wythe clay brick buildings have experienced significant degradation after the introduction of interior insulation, forced air ventilation, and humidification (Mario D. Gonçalves 2007).

The presence of exterior Character Defining Elements in historical buildings prohibits the introduction of exterior insulation; thus, insulation is typically applied over the interior surfaces of the masonry to increase the thermal resistance of the wall section and decrease conductive heat loss. However, during the heating season, the low temperatures on the interior face of the brick masonry fluctuates in cold exterior temperatures and when combined with higher moisture levels in the air promote the formation of condensation within the wall system. In order to rationalize the introduction, location, and type of insulation to heritage buildings, a systematic approach is needed, as for example that provided in NRC's "Guideline for design for durability of building envelopes" (Lacasse, et al.).

Ottawa is qualitatively considered to have a cold, wet winter. However, climate change associated with increases in GHG's is expected to create overall higher ambient temperatures and rain fall. The Ottawa, Ontario historical (current) climate design values from Appendix C of the National Building Code of Canada are summarized in Table 1, and changes in the design parameters associated with global mean temperature increases of $+2.0^{\circ} \mathrm{C}$ and $+3.5^{\circ} \mathrm{C}$ are also provided for comparison purposes (source ECCC). 
Table 1. Current National Building Code environmental loads and predicted loads based on mean global temperature increases of $+2.0 \mathrm{C}$ and $+3.5 \mathrm{C}$. (Gaur, Lacasse, Armstrong)

\begin{tabular}{|c|c|c|c|c|c|c|}
\hline Scenario & $\begin{array}{c}\mathbf{2 . 5 \%} \text { Jan. } \\
\text { Degrees C }\end{array}$ & $\begin{array}{c}\mathbf{2 . 5 \%} \text { July } \\
\text { Degrees C }\end{array}$ & $\begin{array}{c}\text { Degree Days } \\
\text { below 18C }\end{array}$ & $\begin{array}{c}\text { Annual Rain } \\
\text { mm }\end{array}$ & $\begin{array}{c}\text { Snow Load } \\
\text { kPa }\end{array}$ & $\begin{array}{c}\text { Hourly Wind } \\
\text { Press., kPa }\end{array}$ \\
\hline Current & -25.0 & +30.0 & 4440 & 750 & 2.4 & 0.41 \\
\hline$@+2.0^{\circ} \mathrm{C}$ & -17.4 & 32.7 & 3609 & 857 & 1.66 & 0.41 \\
\hline$@+3.5^{\circ} \mathrm{C}$ & -11.7 & 34.4 & 3097 & 933 & 1.23 & 0.41 \\
\hline
\end{tabular}

Current models suggest that in addition to rising mean temperatures, the climate will become wetter with estimated increases in annual precipitation of $8.1 \%$ and $14.4 \%$ for global temperature increases of $2.0^{\circ}$ and $3.5^{\circ} \mathrm{C}$, respectively.

The primary goal of the broader investigation is to reduce the heating and cooling loads for heritage buildings and thus, decrease the contribution of building operations to global GHG's. The application of insulation to increase the thermal resistance of exterior walls was therefore analyzed using hygrothermal modeling to reveal deleterious moisture build-up, based on both the existing historical climate loads and predicted changes in climate from increases in GHG's.

\section{Methodology}

The commercial hygrothermal modeling program, WUFI6.3Pro was utilized for the analysis. The material property input data for WUFI requires the bulk density, porosity, heat capacity, thermal conductivity, and Water Vapour Resistance Factor. Bulk density, porosity, specific heat capacity, and heat conductivity value approximations do not significantly influence the

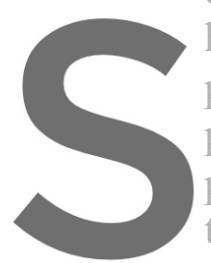
hygrothermal analysis a problem when underta properties for each of th parameters is time cons to permit estimating the materia
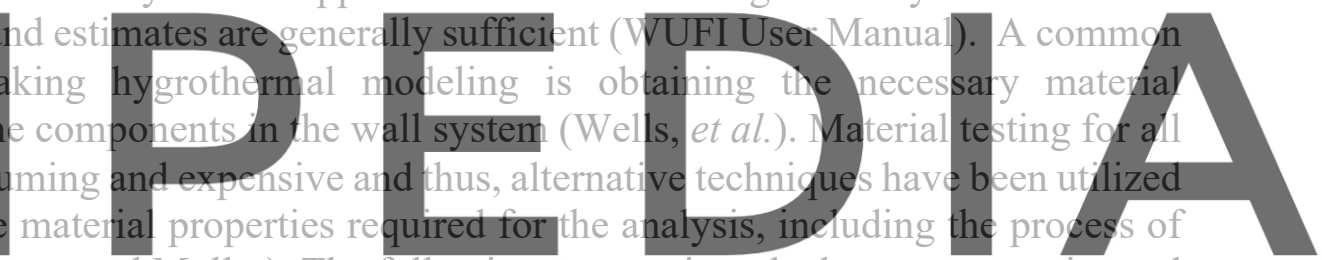

clustering (de Place Hansen and Moller). The following summarizes the known properties and

- Indiana Limestone (exterior): Quarrier provided data on all properties with the exception of Water Vapour Resistance Factor. WUFI Data base on Krensheimer Shelly Limestone has similar properties; therefore, the vapour resistance for Krensheimer Limestone provided by the WUFI data base was used

- Clay brick (e): Brick hygrothermal data available for red clay brick from Ottawa, tested at NRC. Comparative analysis made to WUFI's material data base on Red Matt Clay Brick.

- Parging(d): Historic Lime and Pozzolana from WUFI data base; largely based on permeability.

- Cork(c), Plaster (a), Paint, etc. from North American WUFI Data base

The Wellington Building was designed and substantially complete in 1927. Figure 1 shows the existing building and interior cross-section; the painted plaster, air space, parging over two wythes of red clay brick, faced by exterior Indiana Limestone veneer. The black spots on the parging are the remnants of mastic that was used to bond one-inch cork insulation to the interior face of the parging. 

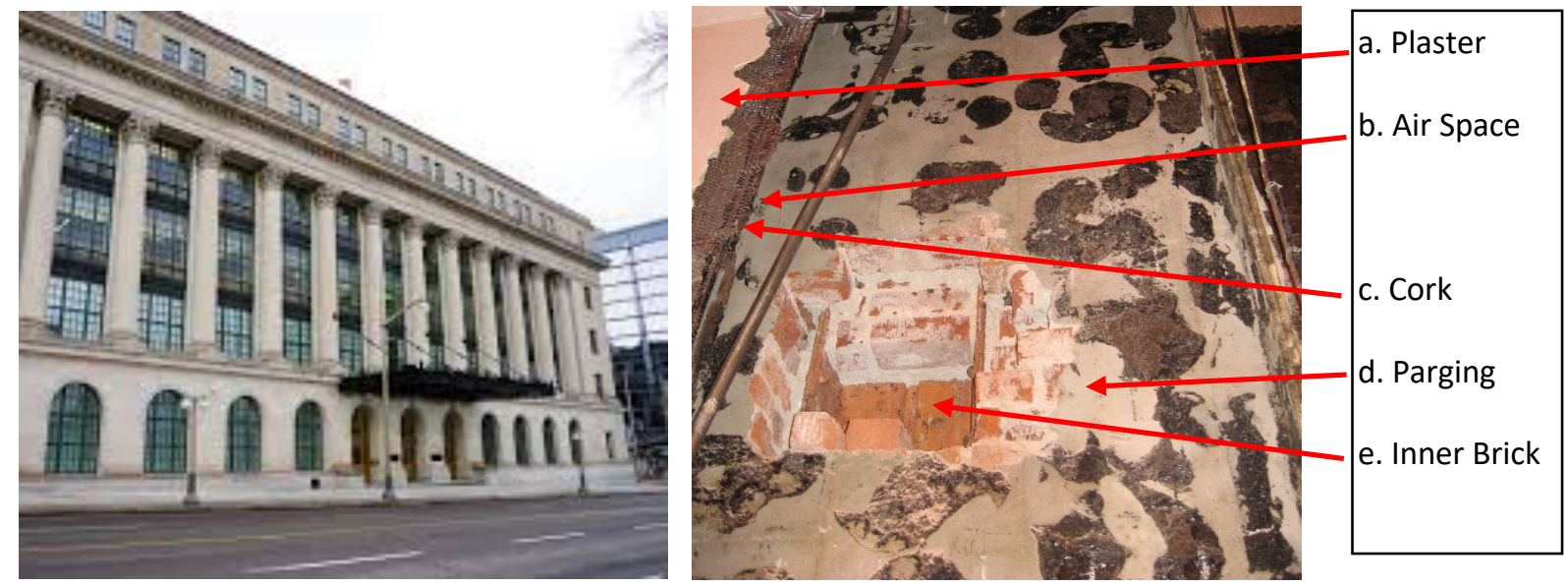

Figure 1. General elevation view and cross section of exterior wall showing parging and interior red brick behind Indiana limestone veneer. Black spots are mastic used to bond one-inch cork insulation (Interior photo courtesy of JM Carriere of Adjeleian Allen Rubeli Ltd.).

For the hygrothermal analysis, the National Research Council of Canada created WUFI compatible hourly climate data files with assistance from Environment and Climate Change Canada (ECCC). Access to both historical and future projected climate data permits, on the basis of results derived from simulation, estimating the durability response for the exterior walls due to changing climatic exposure conditions. Two climate files were provided; NRC1989, representative of the historical climate loads over 31 years (1985-2016), and NRC2074,

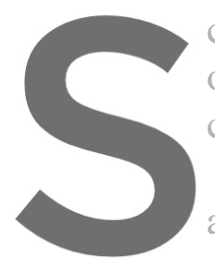
characteristic of the predicted climate of $+3.5 \mathrm{C}$ due to increas case using the WUFI en

A primary component associated with heating ing levels of GHC'S. A
mbedded ASHBAE RP
and cooling loads and the overallinvestiga of insulation to the interior face of the parging (Figure $1 \mathrm{~d}$.) whr ociated with g.obal mean temperatture increase
second set of runs werc completed as the base
325 climatic data file for Ottawa.
ation concerns the reduction in GHG generation
hus, we assessed the impect on the application
Figure 1 d.) which is bonded to the inner wythe of brick. The assumption was, that the existing interior plaster and cork insulation would be

cell polyurethane foam, closed-cell polyurethane foam, and mineral wool insulation. Open cell was chosen to provide air leakage control, and thus an air barrier component on the interior face to reduce interstitial condensation due to its air permeance well below $0.021 /\left(\mathrm{s}-\mathrm{m}^{2}\right)$. Closed-cell foam was chosen to provide both air and vapour diffusion control. Finally, mineral wool was also evaluated because of its reversibility and non-combustibility. Each insulation was covered with painted drywall.

With respect to the level of thermal resistance considered for the retrofit, the energy consultant to the project suggested that economics would likely negate a cost-benefit ratio if more than RSI 1.75 to 2.11 were applied. Thus, the hygrothermal models were based on $75 \mathrm{~mm}$ of open-cell foam, $50 \mathrm{~mm}$ closed-cell foam, and $65 \mathrm{~mm}$ of mineral wool such that all levels of thermal resistance were within close agreement.

\section{Results}

To rationalize the number of hygrothermal model runs to be completed, the existing wall performance, without added insulation was examined based on the climatic data file for ASHRAE 160 embedded into the WUFI program. The ASHRAE 160 - RP1325 historical climate file was found to be generally colder and wetter than that provided in the NRC1989 data and was therefore used as the base or existing case. Four models were run, one for each face of the building, upper elevation to establish the governing case with respect to the largest 
moisture build-up. Based on the building's size and geometry, it was confirmed that the upper north face of the building produced the greatest moisture accumulation for both the existing and projected climate change models, NRC2074. Thus, the focus of the investigation centred on the north face. In total, 24 individual hygrothermal model runs were completed for the analysis using an exposure period of five years. Model results were based on with and without the $1 \%$ retained moisture, as specified in the ASHRAE 160. In addition to modelling the performance of the existing wall cross-section, the impact of introducing three types of insulation was examined, each applied to the thickness required to increase the thermal resistance of the wall section to approximately RSI2.5.

The following table summarizes the results obtained for the existing ASHRAE Year 1 historical climatic load file, and the predicted performance, based on the $3.5^{\circ} \mathrm{C}$ mean increase in global temperature, NRC2074. The results show that conditions tend to stabilize seasonally in years three to five; thus, where relevant, the minimum and maximum moisture content is provided. Where moisture levels continue to increase over time, a " $\wedge$ " has been added to show that the moisture content is generally increasing and not remaining stable over time.

Table 2. Five- year moisture content layer based on existing historical climatic data file and projected climate change model (NRC2074) for base case and insulated wall options.

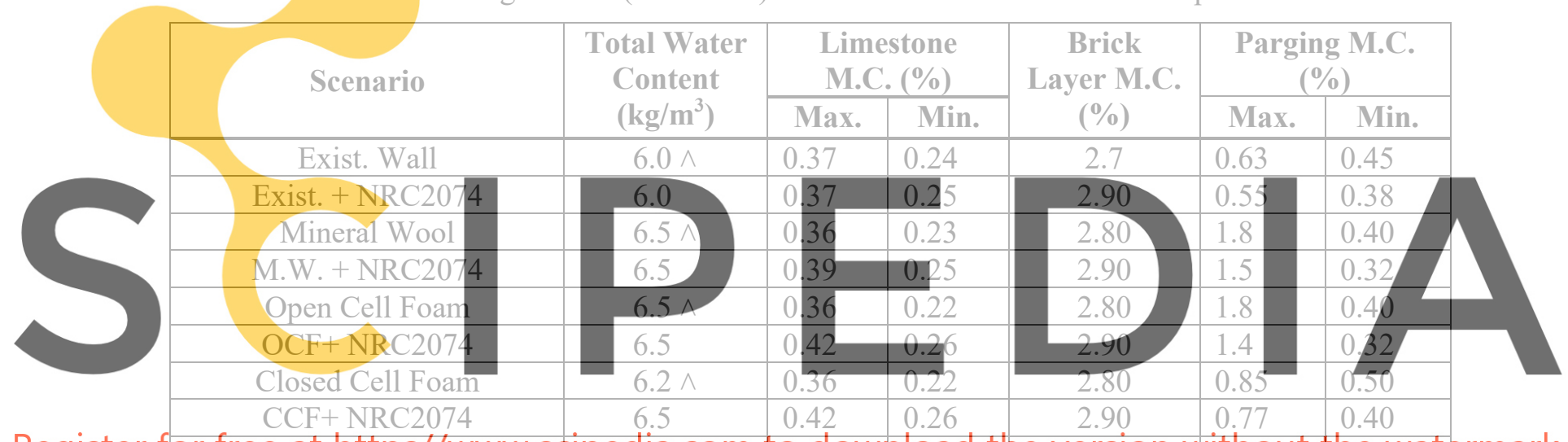

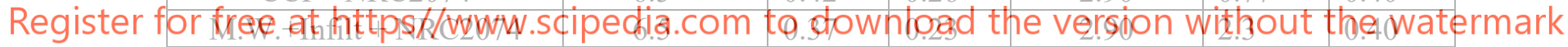

From the information provided in Table 2, it may be seen that although the climate change model produces higher volumes of annual precipitation, no deleterious levels of moisture buildup were observed in the wall system. In fact, moisture levels remained relatively consistent, irrespective of the insulation type applied to the interior face of the walls. Moisture content for all scenarios is well below critical saturation of the masonry materials as the moisture storage capacity for the limestone, brick, and parging is over $70 \mathrm{~kg} / \mathrm{m}^{3}, 50 \mathrm{~kg} / \mathrm{m}^{3}$, and $30 \mathrm{~kg} / \mathrm{m}^{3}$, respectively (WUFI Material Data Base).

The ASHRAE 160 recommendation of $1 \%$ retained moisture is observed to be the primary driver for increasing moisture content in the walls and based on the results for the existing, wall section (with and without insulation), the model results are indicative of continuing increases in moisture with time of exposure. The climate change model, NRC2074 appears however, to stabilize the moisture accumulation in the walls, regardless of the insulation type applied. The information provided in Figures 2 and 3 show the total water content for the mineral wool insulated wall section based on the current historical ASHRAE 160 climate data file, and the predicted climatic file based on the $3.5^{\circ} \mathrm{C}$ mean increase in global temperatures, NRC2074.

From the figures, the total moisture content quickly reaches a semi-asymptotic value for the climate change model whereas the historical data file creates a continuing increase in moisture within the wall system. We postulate that the increasing temperatures, as projected in the future under a warming climate, are facilitating a drying process of the walls. 


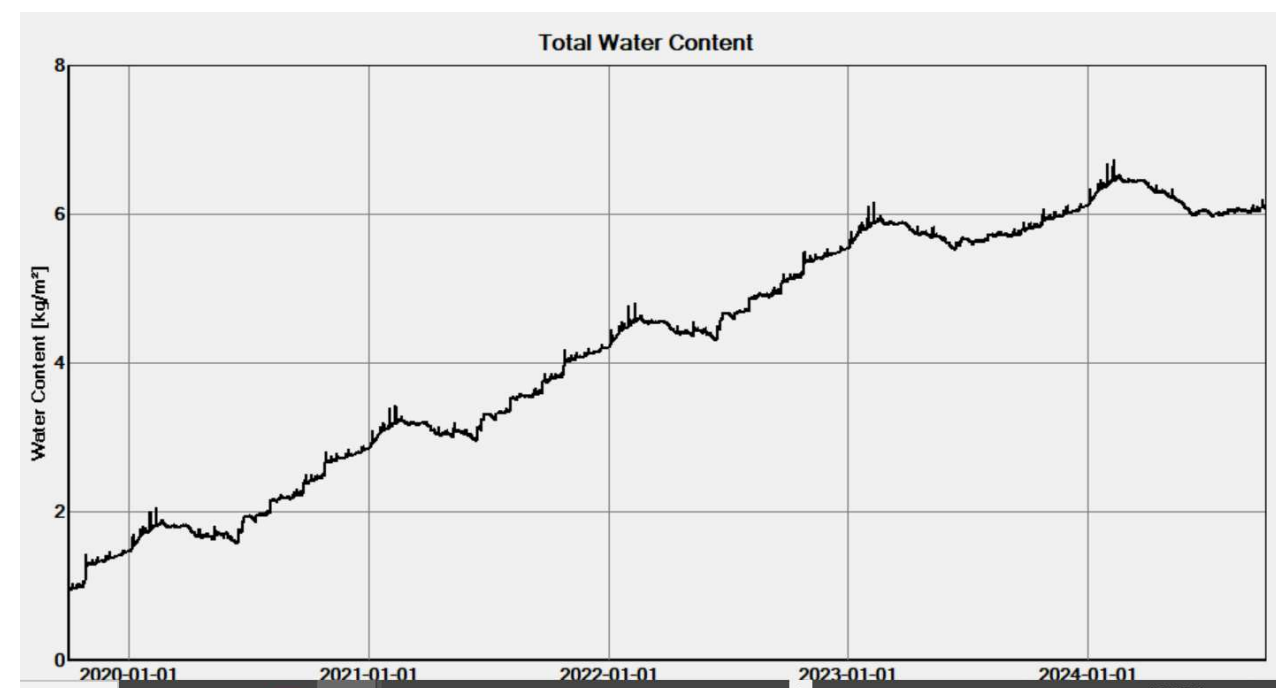

Figure 2. Total moisture content for mineral wool case based on historical ASHRAE 160 climatic data file.

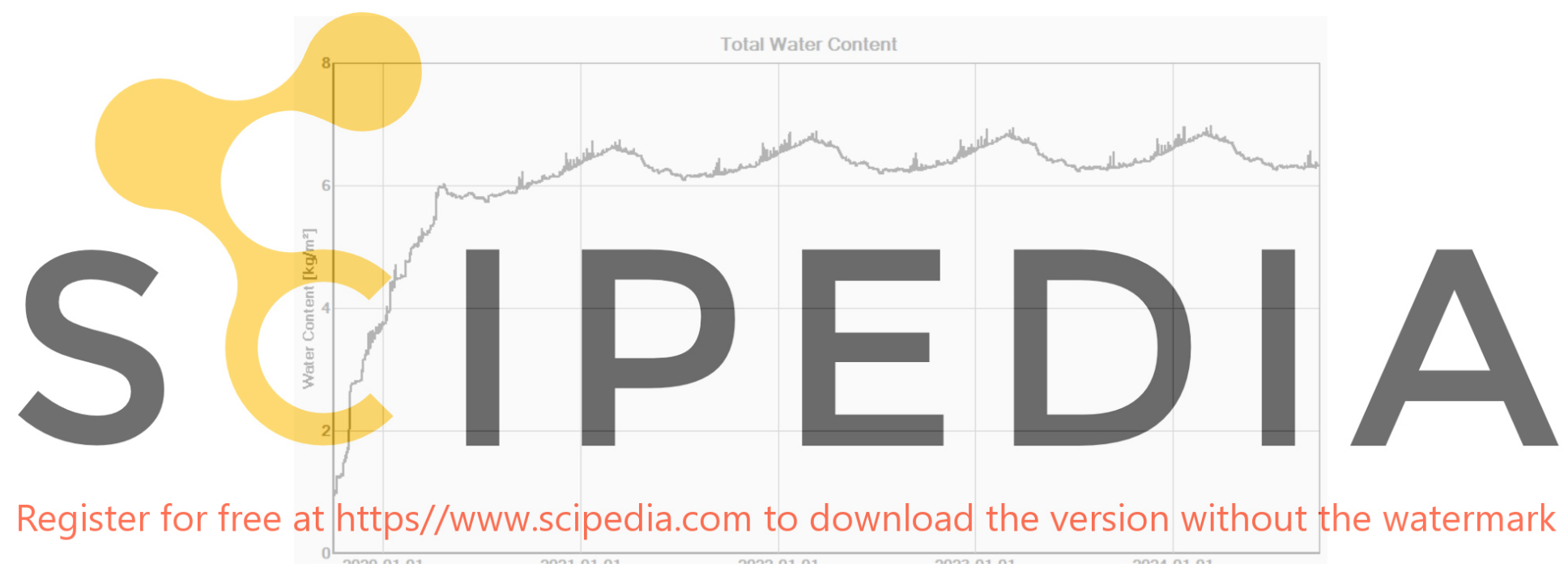

Figure 3. Total moisture content for mineral wool case based on NRC 2074 climate change data file.

One of the principal concerns about the durability of heritage buildings with the inclusion of interior insulation is the potential to reduce masonry wall temperatures below freezing, and to increase the likelihood of freeze-thaw degradation. For the NRC2074 climate file, we introduced air infiltration as a moisture source through the mineral wool insulation model to enable assessing the impact that condensation may have on increasing wall moisture levels. From Table 2, the simulation scenario labelled "M.W. +Infilt. + NRC2074" shows that the moisture levels of the parging and inner wythe of brick predictably increase; however, moisture content remains well below any reasonable limit that might initiate freeze-thaw degradation.

The number of hours per year that the interior face of the parging is below freezing was also found as a simple comparison to evaluate the impact that the different types of insulation have on keeping the interior parging below freezing. A summary of the results of the analysis are given in Table 3; these have been extracted from the WUFI data file in which the mean number of hours per year are provided for the interior parging. It shows the number of hours that the interior parging will be below freezing based on the future projected data (NRC2074) and the same for the historical climate data. 
Table 3. Mean number of hours per year interior parging (bonded to inner brick) is below freezing based on existing and projected climate temperatures for existing wall and insulation options.

\begin{tabular}{|l|c|c|c|c|}
\hline \multicolumn{1}{|c|}{ Climate File } & Existing Wall & $\begin{array}{c}\text { Mineral } \\
\text { Wool }\end{array}$ & $\begin{array}{c}\text { Open Cell } \\
\text { Foam }\end{array}$ & $\begin{array}{c}\text { Closed Cell } \\
\text { Foam }\end{array}$ \\
\hline Historic Climate & $718 \mathrm{hrs}$ & $1514 \mathrm{hrs}$ & $1640 \mathrm{hrs}$ & $1733 \mathrm{hrs}$ \\
\hline Predicted Climate, NRC 2074 & $0 \mathrm{hrs}$ & $604 \mathrm{hrs}$ & $740 \mathrm{hrs}$ & $830 \mathrm{hrs}$ \\
\hline
\end{tabular}

The differences in the number of hours per year below freezing amongst the different types of insulation used to retrofit the walls is a function of the type of material and minor differences in the thermal resistances provided by the various insulation types. Regardless, from the information provided in Table 3, the warming climate predicted with the $3.5^{\circ} \mathrm{C}$ mean global temperature increase will have a dramatic effect by reducing the number of hours the interior parging and inner wythe of brick experiences temperatures below freezing. The warming temperatures may therefore reduce the concern of installing insulation on the interior face of the masonry.

\section{Summary and Conclusion}

Hygrothermal modeling was utilized to establish if projected changes in temperature and precipitation loads predicted by climate change models from a warming climate will impact the durability of a masonry heritage building, located in Ottawa, Canada having insulation introduced on its interior wall face. The significant findings are summarized below.

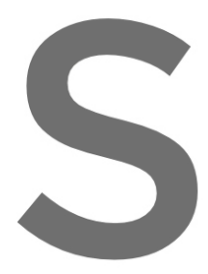

Increasing levels of GHG concentrations has the potential to raise the mean global temperature by $+3.5^{\circ} \mathrm{C}$ degrees. The predicted impact on Ottawa's climate will be
significant, increasing precipitation annually by $14.4 \%$ and decteasing the Janudry
winter design temperature from $-25.0^{\circ} \mathrm{C}$ to $-11.7^{\circ} \mathrm{C}$ or by $53 \%$.
Results show that although the climate change model produces higher volumes of
annual precipitation, no deleterious levels of moisture build-up were observed in the masonry wall systems studied. In fact, moisture levels remained relatively consistent, materials.

- Total predicted moisture content in the wall system quickly reaches a semi-asymptotic value for the climate change model whereas the historical data file creates a continuing increase in moisture within the wall system. The increasing temperatures appear to facilitate drying of the walls.

- The warming climate has a dramatic effect by reducing the number of hours below freezing experienced by the interior parging and wythe of brick. The existing wall section, without insulation was predicted to have no hours below freezing along the interior wythe under future climate change loads versus 718 hours under historic loads. With the inclusion of insulation, the reduction in hours below freezing varies from $60 \%$, $55 \%$, and $52 \%$ for mineral wool, open-cell foam, and closed-cell foam, respectively, under exposure to future climate loads versus historic climate loads.

The placement of insulation on the interior face of masonry walls in heritage buildings is a proposed solution to reducing heating and cooling loads, and thus, to reducing GHG generation. Using hygrothermal analysis, the study shows that the warming temperatures resulting from climate change potentially will substantially reduce the number hours of freezing temperatures experienced by the interior wythe of masonry, maintain the moisture content of the masonry below a damage threshold, and therefore may reduce the potential for freeze-thaw damage to the masonry. The interior application of moderate levels of insulation should therefore be considered for retrofit measures for this heritage building, located in Ottawa, Canada, without increasing the 
risk of damage to the wall. Future studies are proposed which will include a comparative analysis of the hygrothermal results based on testing the actual masonry materials in the Wellington Building in order to validate the material assumptions made in the present study.

\section{Acknowledgements}

The authors sincerely appreciate the contribution of Environment and Climate Change Canada (ECCC) for their contribution to the climate data files, Adjeleian Allen Rubeli for the Wellington Building interior photograph, and Mr. Brennan Sperl, E.I.T. of Crosier Kilgour \& Partners Ltd. for running of the WUFI models.

\section{References}

DePlace Hansen and Moller (2018). How to estimate properties for external walls in historic buildings before applying internal insulation, Energy Efficiency in Buildings.

Environment and Climate Change Canada (2019). Canadian Environmental Sustainability Indicators: Greenhouse Gas Emissions.

Robert Wojcik and Mark Bomberg (2016). Journal of Building Physics, On interior rehabilitation of buildings with historic facades,40(2), 141-161.

Little, Ferraro, and Arregi. Historic Environment. Assessing risks in insulation retrofits using hygrothermal software tools., Scotland Technical Paper 15.

National Building Code of Canada (2015).

Lacasse, Michael, et al, (2018). National Research Council of Canada, Guideline on Design of Durability of Building Envelopes.

Gaur, Lacasse, Armstrong, (2019). Climate data to undertake hygrothermal and whole building simulations under projected climate change influences for 11 Canadian Cities.

Wells, Spewak, (2019). NRC Press/Canadian Journal of Civil Engineering, The use of hygrothermal modeling to validate the applicatic Winnipeg, $M B$.

Wilkinson, DeRose and Su insulation on solid mason
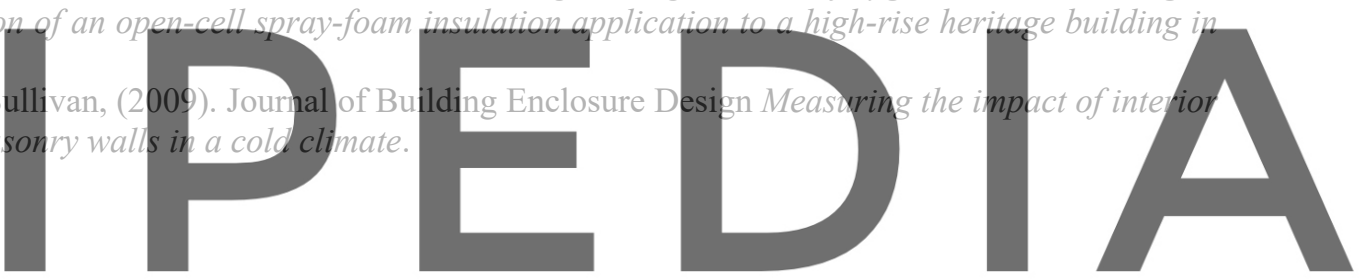

Register for free at https//www.scipedia.com to download the version without the watermark 